\title{
DEVOLUTION AND POST-BREXIT TRADE AGREEMENTS: TOWARDS A JOINT TRADE POLICY COMMITTEE?
}

\author{
Stephanie Switzer and Joseph A McMahon*
}

Edinburgh Law Review (2019) Forthcoming

\section{INTRODUCTION}

In October 2017 when presenting the Policy Paper, Preparing for our Future UK Trade Policy, the Secretary of State for International Trade, Dr Liam Fox, recognised that for the first time since the 1970s, the United Kingdom (UK) would have its own independent trade policy. ${ }^{1}$ Since the last time the UK had an independent trade policy, there have been notable constitutional changes within the UK, notably the creation of devolved administrations in Scotland, Wales and Northern Ireland. All parts of the UK will be differently affected by the decision to leave the European Union (EU) (i.e. Brexit) after 29 March 2019, particularly by the creation of an independent trade policy. As a member of the EU customs union and of the single market, the UK does not at present have an independent trade policy. Instead, trade policy is "largely determined by the EU", a position that will change upon the UK's departure from the EU. While trade is a reserved matter, areas of devolved competence such as agriculture will need to be taken account of in any future UK trade policy. The devolved administrations will require to be involved in what Dr Fox identified as "a once in a lifetime opportunity to build a stronger, fairer and more prosperous United Kingdom that is more open and outward-looking than ever before." 3 Indeed, the Policy Paper mentioned above further recognised that, "( $\mathrm{t}$ )he devolved administrations will have a direct interest in our future trade agreements," 4 with this recognition accompanied by a commitment, "to seek the input of the devolved administrations to ensure they influence the UK's future trade policy, recognising the role they will have in developing and delivering it." 5

In this present paper, we critically review the UK government's current approach to involving the devolved administrations in post-Brexit trade policy development. We demonstrate that there is a significant lack of clarity on the future role of the devolved administrations in the development of trade policy. The Scottish government is particularly concerned in this respect given that its extensive devolution settlement includes areas with significant trade dimensions such as agriculture, fisheries and environmental policy. We argue that greater clarity on such

\footnotetext{
* Lecturer in Law, School of Law, Strathclyde University (stephanie.switzer@ strath.ac.uk) and Full Professor of Commercial Law, UCD Sutherland School of Law (joseph.mcmahon@ucd.ie).

1 Department of International Trade, "Preparing for our UK Trade Policy" (2017) https://www.gov.uk/government/uploads/system/uploads/attachment_data/file/654714/Preparing_for_our_futur e UK trade policy Report Web Accessible.pdf, 4.

2 House of Commons Library, "Briefing Paper - The Trade Bill" (2 July 2018) available at http://researchbriefings.files.parliament.uk/documents/CBP-8073/CBP-8073.pdf, 9.

${ }_{3}$ Trade Policy Report (n 1) 4.

${ }^{4}$ Ibid, 22.

${ }^{5}$ Ibid.
} 
involvement is very much needed and in response, propose the creation of a Trade Policy Committee through an amendment to the Trade Bill.

\section{TRADE AND DEVOLUTION}

The Trade Bill introduced into the House of Commons in November 2017 is designed to ensure that the UK has the necessary powers to conduct an independent trade policy on its departure from the EU. In addition to the creation of a Trade Remedies Authority and providing for regulations to be made to provide UK implementation of the World Trade Organisation's Government Procurement Agreement, it also allows regulations to be made to ensure the continuity of existing trade agreements to which the UK is a party by virtue of its membership of the EU. ${ }^{6}$ It is important to note what the Trade Bill does not cover; the customs/tax-related elements of a future UK trade policy are to be found in the Taxation (Cross-border Trade) Act 2018, which received Royal Assent on 13 September 2018) and it does not provide for the implementation of new trade agreements.

The approach to be taken to new trade agreements was set out by the Secretary of State for International Trade in a statement to the House of Commons on 16 July 2018, which promised that Parliament, the devolved administrations, local government and civil society would be engaged with to ensure that future trade policy worked for all parts of the UK. ${ }^{7}$ It was made clear that the devolved administrations would be "able to inform the Government's approach to negotiations throughout the consultation period and, of course, with subsequent engagement throughout the entire negotiation process." Parliament from Scotland, Wales and Northern Ireland, the Secretary of State reiterated that trade was a reserved matter, noting in response to one question that "we could not go into negotiations with someone sitting on the British side of the table who took a different view from the Government's broader objective for the whole of the United Kingdom." "As a reserved matter, Parliament would be kept updated on the progress of negotiations with primary legislation being laid before Parliament to ratify each trade agreement if it requires changes to existing legislation or where there are no existing powers, in accordance with the 2010 Constitutional Reform and Governance Act (CRAGA). No role is assigned to the devolved administrations under sections 20 to 25 of CRAGA and it is possible that such agreements could impact on the competences of the devolved administrations. ${ }^{10}$

The above situation stands in marked contrast to the position under the Trade Bill, clause $2^{11}$ of which assigns secondary law-making powers to implement international trade agreements, in respect of which the UK is already a party due to its membership of the EU, to both UK ministers and the devolved administrations. In some circumstances those powers may be jointly exercised and in other cases, the devolved administration requires either the consent of, or consultation with, the UK minister before exercising these powers. As the Bill modifies the

\footnotetext{
${ }^{6}$ For further details see Department of International Trade, "Trade Bill Factsheet: UK Trade Legislation" (7 December 2018) available at https://www.gov.uk/government/publications/information-about-the-tradebill/factsheet-our-future-uk-trade-policy\#the-taxation-cross-border-trade-act-2018.

${ }^{7}$ See Hansard: HC Chamber 16 Jul 2018, cols 41 to 43.

8 Ibid, col 42 .

${ }^{9} \mathrm{Ibid}, \mathrm{col} 49$.

${ }^{10}$ The Constitution Committee of the House of Lords is currently holding an enquiry into Parliamentary scrutiny of Treaties; see https://www.parliament.uk/business/committees/committees-a-z/lords-select/constitutioncommittee/inquiries/parliament-2017/parliamentary-scrutiny-of-treaties/

${ }^{11}$ Clauses are numbered in accordance with the Bill as brought forward to the House of Lords.
} 
scope of devolved powers, legislative consent is needed from the devolved administrations. ${ }^{12}$ The Scottish Government has expressed particular concerns regarding the devolution aspects of the Trade Bill, setting out that: ${ }^{13}$

The Scottish Government has been very clear about the serious implications for the Sewel Convention (and the future of devolution) of the recent actions of the UK Government. In particular, we have made it clear that urgent discussions are required on how to protect the Convention before any further legislative consent motions on Westminster Bills ... including the Trade Bill, can be brought forward to the Scottish Parliament.

At present, the Trade Bill is currently at the House of Lords and it is unclear when the Bill will move to Report stage due to the acceptance by the Lords of a motion put forward by Baroness Smith of Basildon that: ${ }^{14}$

(t)he committee's report be not received until Her Majesty's Government has presented to both Houses proposals for a process for making international trade agreements once the United Kingdom is in a position to do so independently of the European Union, including roles for Parliament and the devolved legislatures and administrations in relation to both a negotiating mandate and a final agreement.

One of the issues here is the role of the devolved administrations in the negotiation of international agreements and in this area the Report on the Trade Bill by the House of Lords Select Committee on the Constitution recommended that: ${ }^{15}$

... the Government state whether the existing arrangements of the Joint Ministerial Committee (Europe) for involving the devolved administrations in the negotiation of agreements with the EU will be replicated for trade agreements under the Bill. The Government should also set out how intergovernmental mechanisms will be adjusted to involve the devolved administrations in international relations and treaty-making after Brexit.

The Joint Ministerial Council (JMC) referred to above arises from a Memorandum of Understanding (MOU) between the UK government and the devolved administrations, first agreed in 2001, to promote the principles of good communication, consultation and cooperation. ${ }^{16}$ There are also a number of JMC sub-committees that meet to consider specific issues, for example, JMC(E) which focusses on relations with the EU and JMC(EN) on the

12 For further details on discussions on Legislative Consent for the Trade Bill in Scotland, see https://www.parliament.scot/parliamentarybusiness/Bills/107243.aspx. On a separate note, in August 2018, the Scottish Government set out its vision of, "Scotland's role in the development of future UK trade arrangements," (2018) available at; https://www.gov.scot/publications/scotlands-role-development-future-uk-trade-arrangments/ 13 "Scotland's role in the development of future UK trade arrangements," ibid, 37.

${ }^{14}$ Hansard: HL 21 Jan 2019, cols 507 to 509.

15 House of Lords Select Committee - Constitution Committee, "Trade Bill" available at https://publications.parliament.uk/pa/ld201719/ldselect/ldconst/193/19303.htm\#_idTextAnchor008, para 18.

16 See Memorandum of Understanding and Supplementary Agreements between the United Kingdom Government, the Scottish Ministers, the Welsh Ministers, and the Northern Ireland Executive Committee available at

https://www.gov.uk/government/uploads/system/uploads/attachment_data/file/316157/MoU_between_the_UK_a nd the Devolved_Administrations.pdf. 
negotiations for exiting the EU. The interests of devolved administrations in international relations is set out in a separate concordat which is supplementary to the MOU.

\section{A TRADE POLICY COMMITTEE}

In preparation for the UK's departure from the EU in October 2017, the JMC (E) agreed that common approaches - to be known as Common Frameworks - would be developed in some areas currently governed by EU law but which would fall with the competence of the devolved administrations. ${ }^{17}$ These frameworks, which depending on the policy area, would consist of common goals, minimum or maximum standards, harmonisation, limits on action, or mutual recognition, would be established in areas considered necessary to, inter alia, "enable the functioning of the UK internal market, while acknowledging policy divergence; ensure compliance with international obligations; [and] ensure the UK can negotiate, enter into and implement new trade agreements and international treaties." It was noted that the frameworks will lead to a significant increase in decision-making powers for the devolved administrations. According to the UK Government, legislative common frameworks would be needed in twenty-four policy areas the majority of which fall within the areas of agriculture, food, fisheries and the environment. ${ }^{18}$ The latest Government report indicates that the frameworks outlines are still being developed with the approach being either primary and/or secondary legislation complemented by a memorandum of understanding. ${ }^{19}$

In the absence of common frameworks which address issues surrounding international relations, and especially trade, the UK government and the devolved administrations may fall back on the Concordat on International Relations. This confirms the reserved power of the UK Government in international relations and promises consultation with the devolved administrations on the formulation of the UK's position for international negotiations in areas that fall within devolved competences. ${ }^{20}$ However, it is also made clear that in such international negotiations, it may be appropriate for Ministers or officials from the devolved administrations to form part of a UK negotiating team advancing a single negotiating line which the Ministers (or officials) have played a part in developing. ${ }^{21}$ The Concordat confirms that the devolved administrations are responsible for observing and implementing international obligations which relate to devolved matters, ${ }^{22}$ and it recognises that "[T] will, under normal circumstances, not ask the UK Parliament to legislate in any area for which

17 Joint Ministerial Committee (EU Negotiations) Communique (16 October 2017) available at https://assets.publishing.service.gov.uk/government/uploads/system/uploads/attachment data/file/652285/Joint Ministerial Committee communique.pdf.

${ }^{18}$ It was estimated that non-legislative common frameworks would been needed in 82 policy area and that no further action was required in 42 policy areas. See https://assets.publishing.service.gov.uk/government/uploads/system/uploads/attachment_data/file/686991/20180 307 FINAL_Frameworks analysis for publication on 9 March 2018.pdf. For discussion see Paun A, "Common UK Frameworks after Brexit" (2018) available at https://sp-bpr-en-prodcdnep.azureedge.net/published/2018/2/2/Common-UK-Frameworks-after-Brexit/SB\%2018-09.pdf.

${ }^{19}$ See Cabinet Office, "The European Union (Withdrawal) Act and Common Frameworks 26 June 2018 to 25 September 2018", available at https://assets.publishing.service.gov.uk/government/uploads/system/uploads/attachment data/file/755498/EUWithdrawal-Act-Schedule-3-Report.pdf, para 1.13.

${ }^{20}$ Memorandum of Understanding (n 16), para D1.3 (Scotland). There are separate Concordats for Scotland (D1), Wales (D2), Northern Ireland (D3) and a Common Annex (D4).

${ }^{21}$ Ibid, para D4.7.

${ }^{22}$ Ibid, para D1.6 (Scotland). 
legislative competence has been devolved except with the agreement of the devolved legislature." 23

However, it should also be noted that each country-specific concordat makes it clear that it is "not intended to constitute a legally enforceable contract or to create any rights or obligations that are legally enforceable" and that the relevant legislation devolving power takes precedence. ${ }^{24}$ This legislation gives the UK Government the power to ensure that the devolved administrations take action to give effect to international obligations and also do not take actions which would be incompatible with these obligations. For example, under section 35 of the Scotland Act, the Secretary of State may make an order prohibiting the Presiding Officer from submitting a Bill of the Scottish Parliament for Royal Assent if s/he has reasonable grounds to believe that it contains provisions which would be incompatible with any international obligations of the UK. ${ }^{25}$ Likewise, section 58 of the Scotland Act 1998 gives the UK Government the power to order that a proposed action by the Scottish Parliament should not be taken if it would be incompatible with any international obligation of the UK or direct that action be taken to give effect to any such obligation. ${ }^{26}$ It is also possible for the UK Government to revoke any devolved legislation if it contains provisions which would be incompatible with any international obligations.

Such legislation, particularly within the context of the future development of trade policy, could possibly create constitutional tensions within the UK and a means must be found to eliminate such a possibility. In this regard, the Scottish Government has proposed the establishment of a, "new statutory intergovernmental international trade committee." 27 A possible model to utilise in this regard would be the experience of the EU in the trade policy area. Article 207(3) of the Treaty on the Functioning of the EU (TFEU) provides for a Trade Policy Committee (TPC) to assist and advise the Commission in negotiating agreements with third countries or in international organisations (for example, the World Trade Organisation) that fall within the scope of the Common Commercial Policy and is one of the preparatory bodies assisting the Council in making decisions in this area. ${ }^{28}$ One such decision is the authorisation granted on a Commission request, for example, to negotiate a new trade agreement with a trade partner; this authorisation establishes what the Commission should achieve in the agreement. Article 207(3) also requires the Commission to report regularly to the TPC and to the European Parliament on the progress of negotiations; this is one area in which an enhanced role has been given to the European Parliament. Although the European Parliament does not have the same status as

\footnotetext{
${ }^{23}$ Ibid, para D4.11. The paragraph recognises that the UK Government may legislate "for reasons such as urgency, where full consultation and agreement is impractical."

${ }^{24}$ Ibid, para D1.2 and D1.8. See also para A1.10 which makes it clear that the MOU is not legally binding and agreement reached as a result of discussions are also not legally binding.

${ }^{25}$ See also ss 101 and 114 of the Government of Wales Act 2006 and s 14 of the Northern Ireland Act 1998.

${ }^{26}$ See also s 82 of the Government of Wales Act 2006 and s 26 of the Northern Ireland Act 1998.

27 "Scotland's role in the development of future UK trade arrangements" (n 12) 53. See also Welsh Government,

"Trade Policy: The Issues for Wales" (2018) available at https://beta.gov.wales/sites/default/files/2018-

01/180202-trade-policy-the-issues-for-wales.PDF which calls for a UK Council of Ministers or, as an interim measure, a Joint Ministerial Committee on International Trade.

28 There are other configurations of the Committee dealing with aligned issues such as services. The TPC was previously known as the Article 133 Committee. See for example, Leal-Arcas, R The EC in the WTO: The threelevel game of decision-making. What multilateralism can learn from regionalism European Integration online Papers (EIoP) Vol. 8 (2004) $\mathrm{N}^{\circ}$ 14, available at http://eiop.or.at/eiop/texte/2004-014a.htm.
} 
the TPC, it is given an enhanced role in the adoption of measures under the Common Commercial Policy.

Within this framework as adapted to the UK, the UK Government would be treated as if it were the Commission; being both the initiator of negotiating proposals and the body conducting the negotiations. The devolved administrations would be treated as if they were the Member States, thereby being consulted on the development of the negotiating guidelines for an international agreement. They would also be regularly informed of the progress of negotiations and in matters falling within the competence of the devolved administrations, would be part of the negotiating team. Once concluded, the agreement would have to be ratified, through the affirmative procedure, by both the UK Parliament and by the devolved legislatures. ${ }^{29}$ Again, borrowing from EU law, the UK Government and the devolved administrations would be under a legal duty to cooperate on the negotiation, conclusion and implementation of agreements falling within areas of the competence of the devolved nations. ${ }^{30}$ Adoption of this framework would be effected through an amendment to the Trade Bill, thus giving it legislative force. The TPC could apply to ongoing negotiations in respect of the 'roll over' of existing international trade agreements where significant changes are envisaged, new trade negotiations and also negotiations within the WTO.

\section{CONCLUSIONS}

It is clear that the UK government's current approach to involving the devolved nations in postBrexit trade policy development lacks clarity. This has prompted the House of Lords to agree to a motion during the Committee stage of the Trade Bill which requires the UK Government to set out the role of Parliament and the devolved legislatures and administrations in respect of the negotiation and final agreement to international trade agreements. Partly in response to this, we proposed the creation of a UK Trade Policy Committee through an amendment to the Trade Bill. Modelled on an existing mechanism under EU law, the creation of a UK TPC could help address at least some of the tensions surrounding the role of the devolved nations in trade policy development post-Brexit.

\footnotetext{
${ }^{29}$ Implementation of this aspect of the proposal would require amendment of the 2010 Constitutional Reform and Governance Act.

${ }^{30}$ See Article 3 of the Treaty on European Union.
} 